Reprod. Nutr. Dévelop., 1985, 25 (6), 1075-1081.

\title{
Effect of protozoa on rumen protein degradation in sheep
}

K. USHIDA $(*)$, J.-P. JOUANY

Laboratoire de la Digestion des Ruminants, I.N.R.A., Theix, 63122 Ceyrat, France.

(*) Department of animal Science, College of Agriculture, Kyoto University, Kyoto, Japan 606.

\section{Summary.}

1. We have studied the contribution of ciliate protozoa to the degradation of dietary protein, utilizing 5 defaunated and 6 faunated sheep. Rumen samples from these animals were used as inocula for in vitro determination of the degradability of different protein sources : lupine grain, peanut and soybean cake, and fish meal. We also applied the in sacco method to measure the digestibility of soybean proteins. Two pore sizes (50 and $100 \mu \mathrm{m})$ were used in the in sacco study. The nitrogen degradation curve was constructed according to the mathematical model : $P(t)=a+b\left(1-e^{-c t}\right)$, and the parameters $a, b$, and $c$ were determined for both faunated and defaunated animals. The proteolytic activity of the rumen contents was also determined using azocasein.

2 . The in vitro degradability of proteins was significantly less in defaunated than in faunated animals : 17, 19, 28 and $64 \%$ with lupine grain, peanut cake, soybean cake and fish meal proteins, respectively. The protozoal effect was greater when protein solubility was low.

3. The in sacco study showed that neither the protozoa nor bag pore size had any effect on the protein fraction (a) immediately soluble in the rumen juice. However, both factors increased the insoluble, potentially degradable fraction " $b$ " $(P \leqslant .01)$. Protozoa had a positive effect on the rate of degradation (c) of the fraction $b$. This effect was most clear with the $100 \mu \mathrm{m}$ bags. The significant interaction between protozoa and pore size on factor « $c$ " showed that large ciliate protozoa $(100 \mu \mathrm{m})$ were directly involved in determining this parameter.

4. Taking into account the very soluble azocasein utilized in this study to determine the protease activity of rumen juice, we confirmed the dominant effect of bacteria on the degradation of very soluble proteins. Conversely, protozoa, particularly large Ophryoscolecidae $(100 \mu \mathrm{m})$, increased the ruminal degradation of relatively insoluble proteins.

\section{Introduction.}

The role of protozoa in the ruminal digestion of nitrogen is not well known. It has been reported that their presence in the rumen causes an increase in rumen ammonia-nitrogen (Jouany and Senaud, 1982, 1983) and that their contribution to the amount of microbial protein entering the small intestine is low (Weller and Pil- 
grim, 1974). Recently, other authors have shown that the duodenal flows of nonammonia nitrogen (Ushida et al., 1984) and of amino acids (Veira et al., 1984) are significantly higher in sheep with no protozoa present in the rumen (defaunated). In Ushida et al. (1984), the increase in nitrogen flow was due to increased flows of dietary and bacterial proteins.

The purpose of the present study using in vitro and in sacco techniques was to determine the role of rumen protozoa in the degradability of different protein sources. An abstract of this work has already been presented by Ushida and Jouany (1985).

\section{Material and methods.}

Animals and diets. - Five defaunated and 6 faunated Texel wether sheep laverage wgt : $60 \mathrm{~kg}$ ) were used as rumen content donors during the in vitro study. Three defaunated and 3 faunated sheep were used for the in sacco experiments. Each sheep was fitted with a rumen cannula $(\varnothing 60 \mathrm{~mm})$ and penned individually. The animals were defaunated at least 2 months before the experiments began, as described by Jouany and Senaud (1979a).

Each sheep received a daily ration containing $800 \mathrm{~g}$ of pelleted lucerne hay, $200 \mathrm{~g}$ of chopped wheat straw, $250 \mathrm{~g}$ of mixed grass hay and $150 \mathrm{~g}$ of pelleted barley. The diet was given in two equal portions at 12-hour intervals. Water and a mineral lick were always available, except during the night before the rumen contents were sampled for in vitro study.

In vitro study. - In vitro degradabilities of lupine, peanut cake, soybean cake and fish meal proteins were measured with either defaunated or faunated rumen contents using the method of Vérité and Demarquilly (1978) modified by Jouany and Thivend (1985). The protein to be tested was incubated with both rumen fluid and rumen particle matter. The nitrogen requirement of the microbes was supplied by additional non-protein nitrogen. The ammonia produced from the protein substrate was estimated by comparing ammonia production to a control fermenter containing the same amount of organic matter but with no protein added.

Each protein source was incubated in both defaunated and faunated rumen contents on the same day; at least five determinations were made for each protein source.

The protease activity of defaunated and faunated rumen contents was measured as described by Brock et al. (1982) with ten determinations for each group of sheep.

In sacco study. - The nylon bag method was used to measure soybean cake protein degradability in defaunated and faunated sheep rumens. The heat-sealed bags, measuring $11 \times 6.5 \mathrm{~cm}$, were made of nylon cloth having a calibrated pore size of either 50 or $100 \mu \mathrm{m}$ (Blutex XX, Tripette et Renaud, Paris, France).

Approximately $3 \mathrm{~g}$ of soybean cake, ground through a $3 \mathrm{~mm}$ sieve, were put into each bag. Five bags of $50 \mu \mathrm{m}$ pore size and 5 of $100 \mu \mathrm{m}$ pore size were fixed on a ferric chain $30 \mathrm{~cm}$ long connected to the plug of the rumen cannula. The bags were introduced into the rumen just before the morning feeding and incu- 
bated for 2, 4, 6, 12 and $24 \mathrm{~h}$. At the end of incubation, the bags were removed from the rumen and washed at least four times in cold water with a simple manually-operated washing apparatus. They were then squeezed gently by hand and dried at $80^{\circ} \mathrm{C}$ for $48 \mathrm{~h}$. The dried bags were weighed to determine the amount of residual dry matter. The residue was ground and its nitrogen content determined by the Kjeldahl method.

The degradation rate of soybean cake protein was estimated by fitting the results to the model of $\emptyset$ rskov and McDonald $(1979): p(t)=a+b\left(1-e^{-c t}\right)$ where " a " represents the rapidly soluble $N$ fraction, « $b$ " the insoluble but potentially degradable $N$ fraction, and « $c$ " the degradation rate of the " $b$ " fraction. The parameters $\mathrm{a}, \mathrm{b}$ and $\mathrm{c}$ were estimated by Facom-M 382 at the Data Processing Center of Kyoto University using its SALS package.

The significance of the difference between the means in each experiment was determined by analysis of variance.

\section{Results.}

The faunated sheep had approximately $5.10^{5}$ protozoa $/ \mathrm{ml}$ in their rumen. The population consisted of $80-90 \%$ Entodinium sp., $10-20 \%$ Polyplastron multivesiculatum and $10-20 \%$ Holotrichs. A small number of Enoploplastron was present in some sheep. The defaunated sheep had no protozoa at any time during the experiment.

The effect of protozoa on in vitro nitrogen degradability of lupine, peanut cake, soybean cake and fish meal is shown in table 1 . The values obtained with

\section{TABLE 1}

Effect of protozoa on "in vitro " degradability of various protein sources (Percentage of degradable $\mathrm{N}$ in total $\mathrm{N}$; mean \pm s.e.).

\begin{tabular}{lccc}
\hline \multicolumn{1}{c}{ Source } & DF & $F$ & $\begin{array}{c}\text { Statistical } \\
\text { significance }\end{array}$ \\
\hline Lupin & $60.7 \pm 3.4$ & $70.9 \pm 2.4$ & $P \leqslant 0.01$ \\
Peanut cake & $60.2 \pm 2.4$ & $71.7 \pm 2.8$ & $P \leqslant 0.05$ \\
Soybean cake & $37.2 \pm 2.7$ & $47.6 \pm 1.9$ & $P \leqslant 0.05$ \\
Fish meal & $17.0 \pm 1.4$ & $27.9 \pm 2.9$ & $P \leqslant 0.05$ \\
\hline
\end{tabular}

D F : incubated with defaunated rumen contents ; F : incubated with faunated rumen contents.

defaunated rumen contents were always lower than those found with faunated rumen contents. The difference in nitrogen degradability between the two animal types was an absolute constant for all tested protein sources (approximately 10 points). In relative values, the presence of protozoa had a greater effect on proteins with low degradability. A linear correlation was observed between in vitro 
degradability (fig. 1) measured with faunated rumen contents ( $Y$ ) and that measured with defaunated rumen contents $(X): Y=13.68+0.93 \times(r=0.935)$.

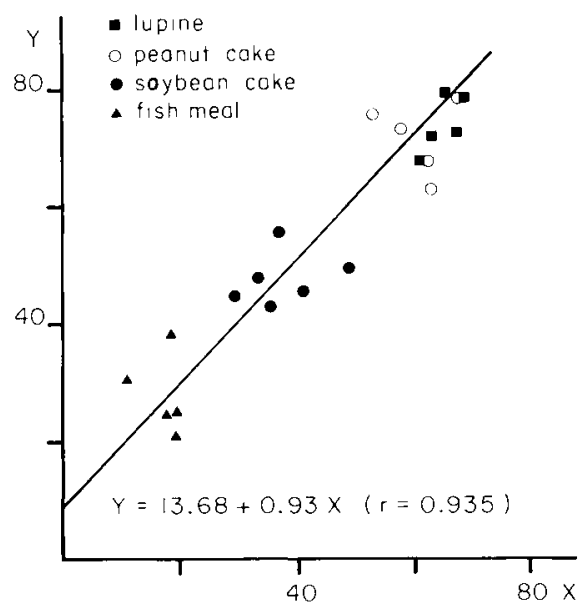

FIG. 1. - Linear correlation of nitrogen ( $N$ ) degradability between faunated and defaunated rumen contents.

The protease activity of rumen contents used for in vitro measurement was significantly $(P \leqslant 0.05)$ lower in faunated than in defaunated sheep $10.64 \pm 0.03$ vs $0.82 \pm 0.06 \mathrm{mg}$ of azocasein hydrolysed $\mathrm{ml}^{-1}$ rumen contents. $\mathrm{h}^{-1}$ ).

The effect of protozoa on the degradability of soybean cake protein, measured by the in sacco method, is shown in table 2. There was no significant difference between defaunated and faunated sheep for parameter "a " which is considered to be the rapidly soluble fraction. Pore size had no significant effect on this parameter either. However both the presence of protozoa and the use of the larger pore size significantly increased parameters " $b$ » and " $c$ ». Both had a significant effect on parameter $" b$ $)(P \leqslant 0.01)$; the pore size had a greater effect $(P<0.01)$ than the protozoa $(P \leqslant 0.05)$ on parameter $(C)$. The interaction of these two factors on parameter $" C$ » was also significant $(P<0.05)$.

\section{TABLE 2}

Effect of protozoa on protein degradability of soybean cake measured with the " in sacco " method.

\begin{tabular}{|c|c|c|c|c|c|c|c|c|c|}
\hline \multirow{2}{*}{ Pore size $(\mu \mathrm{m})$} & \multicolumn{2}{|c|}{ D F } & \multicolumn{2}{|c|}{$\mathrm{F}$} & \multirow{2}{*}{ sme } & \multirow{2}{*}{$\begin{array}{c}\text { F } \\
\text { vs. } \\
\text { D F }\end{array}$} & \multirow{2}{*}{$\begin{array}{c}50 \mu \\
\text { vs. } \\
100 \mu\end{array}$} & \multirow{2}{*}{\multicolumn{2}{|c|}{ Interaction }} \\
\hline & 50 & 100 & 50 & 100 & & & & & \\
\hline a $\{\%\}$ & 14.4 & 15.0 & 16.8 & 15.0 & 0.8 & NS & NS & NS & NS \\
\hline$b(\%)$ & 70.4 & 79.8 & 78.6 & 84.9 & 1.7 & $* *$ & $* *$ & NS & \\
\hline$c\left(h^{-1}\right)$ & 8.7 & 9.1 & 8.7 & 10.4 & 0.2 & * & ** & * & \\
\hline
\end{tabular}

D F : incubated in defaunated rumen ; $F$ : incubated in faunated rumen.

$a, b, c:$ parameters of $P(t)=a+b\left(1-e^{-c t}\right)(\emptyset$ rskov and McDonald, 1979).

${ }^{*} \mathrm{P} \leq 0.05 ; * * \mathrm{P} \leq 0.01$; NS : Not Significant. 


\section{Discussion.}

\section{In vitro determination.}

Protozoa have a negative effect on the number of bacteria in the rumen (Eadie and Gill, 1971 ; Demeyer and Van Nevel, 1979). Furthermore, our results show that the easier the protein is degraded, the less effect the protozoa have in relative values. This pattern confirms the data of Onodera and Kandatsu (1970) and of Nugeant and Mangan (1981). According to Siddons and Paradine (1981), the first factor determining the degradation of soluble proteins is the size of the bacterial population, probably because soluble proteins are in contact with the bacterial surface where proteases and peptidases are located (Nugeant and Mangan, 1981). Therefore, the degradation of soluble proteins may be more intense in the defaunated than in the faunated rumen. This hypothesis is supported by the fact that proteolytic activity was higher in defaunated animals when measured using azocasein which is totally soluble.

\section{In sacco determination.}

The amount of rapidly soluble protein, fraction " a ", is a physical characteristic of each protein source. As with the in vitro results, we found that the presence of protozoa in the rumen has no effect on the soluble protein fraction.

The insoluble and potentially-degradable protein, fraction " $b$ », is the result of the combined attacks of both bacteria and protozoa which have completely different modes of degradation. The protozoa ingest entire feed particles, while the bacteria adhere to the particle surface. Like Kayouli et al. (1983), our results show that in the presence of protozoa, which generally cause a decrease in bacterial numbers, the degradability of fraction " $b$ " and the rate of its degradation (c) are higher than in the defaunated rumen. Protozoal ingestion of dietary particles causes an increase in the relative enzyme concentration in respect to the particle and more direct enzyme-substrate contact in the cytopharynx of ciliates.

Protozoa also have a positive effect on the degradation of plant cell walls (Jouany and Senaud, 1979b), making the intracellular proteins more accessible to enzyme degradation. Cell wall breakdown is often the limiting factor in the proteolytic process in the rumen (Ganev et al., 1979). The increase in fraction « b " degradability, seen when the pore size of the bags was increased, can be explained by increased physical loss from the bags. In effect, the measured differences between the 50 and $100 \mu \mathrm{m}$ mesh size are equivalent, being slightly greater in defaunated than in faunated animals.

Protozoa had no effect on the degradation rate " $c$ " of fraction " $b$ " in the $50 \mu \mathrm{m}$ mesh bags ; however, there was a significant effect with the $100 \mu \mathrm{m}$ bags, indicating that small Ophryoscolecidae $(<50 \mu \mathrm{m})$ as well as /sotrichidae, the only ciliates capable of entering the $50 \mu \mathrm{m}$ bags, had no effect on proteolysis rate in the rumen. It is also possible that this parameter could be more strongly influenced by larger Ophryoscolecidae $(100 \mu \mathrm{m})$. These conclusions are supported by the statistical significance of the protozoa-pore size interaction.

Ørskov and McDonald (1979) have proposed another model to predict effec- 
tive ruminal protein degradation : $P(\%)=a+(b c) /(c+k r)$, where $k r$ is the outflow rate of marked particles from the rumen. In the present study, the outflow of protein particles was no measured. However, Kayouli et al. (1983) and Ushida et al. (unpublished data) found an increase in the rumen outflow rate of chromium mordanted soybean cake or lucerne hay following defaunation. These results suggest that protein particles stay in the rumen for a shorter time and thus are exposed to less intense proteolysis when the protozoa are removed from the rumen. According to this model and using the $\mathrm{kr}$ value of Ushida et al. (unpublished data), we observed that the predicted degradation " $p$ " increased by 10 points when protozoa were present $(0.55$ vs 0.65$)$.

By eliminating the effect of protozoa on protein degradability and protein retention time in the rumen, defaunation produces a net decrease in protein degradation. Our in vitro and in sacco results were recently confirmed by in vivo work carried out by Ushida et al. (1984). In the course of that study, the authors found that the flow of duodenal feed nitrogen was significantly increased by ruminal defaunation. Our study suggests that the in vivo effects of defaunation would be more evident when the dietary proteins are not readily soluble.

Reçu en mai 1985.

Accepté en septembre 1985.

Acknowledgements. - The authors are grateful to Mr. J. Lefaivre for surgical preparation of the animals and to Mr. L. L'Hôtelier, Mr. M. Fabre and Mr. P. Pichon for care of the experimental animals. The authors thank Mr. Hirooka, Laboratory of Animal Resource, Kyoto University, for his help in the processing of the data. One of the authors (Mr. K. Ushida) is indebted to the French government (" Centre International des Etudiants et des Stagiaires ") for a grant to work at the "Institut National de la Recherche Agronomique " at Theix.

Résumé. Influence des protozoaires du rumen sur la dégradation des protéines chez le mouton.

Nous avons étudié l'action des protozoaires ciliés sur la dégradation des protéines alimentaires en utilisant 5 moutons défaunés et 6 moutons faunés. Nous avons déterminé la dégradabilité in vitro de différentes sources protéiques (graine de lupin, tourteau d'arachide et de soja, farine de poisson) à l'aide d'inoculums provenant soit des animaux défaunés soit des animaux faunés. Nous avons également mesuré la dégradabilité in sacco des protéines de soja. La courbe de dégradation de l'azote a été construite selon le modèle mathématique $\left(P(t)=a+b\left(1-e^{-c t}\right)\right.$ ce qui a permis de déterminer les paramètres $a, b$ et $c$ à la fois pour les animaux faunés et défaunés. Enfin nous avons mesuré l'activité protéolytique de leur contenu de rumen.

La dégradabilité in vitro des protéines a été plus faible chez les animaux défaunés. La diminution a été respectivement de $17,19,28$ et $64 \%$ pour la graine de lupin, les tourteaux d'arachide et de soja, la farine de poisson. L'effet des protozoaires a été d'autant plus important que la solubilité de la protéine était faible.

L'étude réalisée in sacco a montré que la fraction d'azote immédiatement solubilisée dans le rumen (a) n'est pas influencée par la présence de protozoaires ni par la taille des mailles des sachets. En revanche, ces deux facteurs, ont augmenté la valeur de la fraction d'azote insoluble et potentiellement dégradable (b) $(P \leqslant 0,01)$. Les protozoaires ont également eu un effet positif sur la vitesse de dégradation (c) de la fraction « b ". Cet effet a été particulièrement net avec les sachets de $100 \mu$. L'interaction significative entre les proto- 
zoaires et la taille des mailles sur le facteur " $\mathrm{c}$ " montre que les ciliés de grande taille $(100 \mu)$ sont directement impliqués dans l'évolution de ce paramètre.

La mesure de l'activité protéasique du jus de rumen effectuée à l'aide d'une protéine très soluble (azocaséine), a confirmé l'effet dominant des bactéries sur la dégradation de la portion soluble de l'azote protéique. Les protozoaires, et plus particulièrement les gros Ophryoscolecidae $(100 \mu)$ ont eu une action particulièrement nette sur la dégradation de la fraction azotée peu soluble.

\section{References}

BROCK F. M., FORSBERG C. W., BUCHANAN SMITH J. G., 1982. Proteolytic activity of rumen microorganisms and effect of proteinase inhibitors. Appl. environ. Microbiol., 44, 561569.

DEMEYER D. I., VAN NEVEL C. J., 1979. Effect of defaunation on the metabolism of rumen microorganisms. Br. J. Nutr., 42, 515-569.

EADIE J. M., GILL J. L., 1971. The effect of the absence of rumen ciliate protozoa on growing lambs fed on a roughage-concentrate diet. Br. J. Nutr., 26, 155-167.

GANEV G., ØRSKOV E. R., SMART R. I., 1979. The effect of roughage or concentrate feeding and retention time on total degradation of protein in the rumen. J. agric. Sci. Camb., 93, 651-656.

JOUANY J. P., SENAUD J., 1979a. Defaunation du rumen de mouton. Ann. Biol. anim. Bioch. Biophys., 19, 619-624.

JOUANY J. P., SENAUD J., 1979b. Role of rumen protozoa in the digestion of food cellulosic materials. Ann. Rech. vét., 10, 261-263.

JOUANY J. P., SENAUD J., 1982. Influence des ciliés du rumen sur la digestion de différents glucides chez le mouton : I - Utilisation des glucides pariétaux (cellulose et hémicelluloses) et de l'amidon. Reprod. Nutr. Dévelop., 22, 735-752.

JOUANY J. P., SENAUD J., 1983. Influence des ciliés du rumen sur la digestion de différents glucides chez le mouton : II - Régimes contenant de l'inuline, du saccharose et du lactose. Reprod. Nutr. Dévelop., 23, 607-623.

JOUANY J. P., THIVEND P., 1985. In vitro effects of avoparcin on protein degradability and rumen fermentation (submitted to Anim. Feed Sci. Technol.).

KAYOULI C., VAN NEVEL C. J., DEMEYER D. I., 1983. Effet de la défaunation du rumen sur la dégradabilité des protéines du soja mesurée in sacco, 251-253. IVe int. Symp. on protein metabolism and nutrition. Vol. II. Les colloques de I'I.N.R.A. n' 16 - I.N.R.A. Publ. éd., Rte de St Cyr, 78000 Versailles, France.

NUGEANT J. M., MANGAN J. L., 1981. Characteristics of the rumen proteolysis of fraction I leaf protein from lucerne (Medicago sativa L). Br. J. Nutr., 46, 39-58.

ONODERA R., KANDATSU M., 1970. Amino acids and protein metabolism of rumen ciliate protozoa. IV - Metabolism of casein. Jap. J. zootech. Sci, 41, 307-313.

ØRSKOV E. R., MCDONALD I., 1979. The estimation of protein degradability in the rumen from incubation measurements weighted according to rate of passage. J. agric. Sci. Camb., 92, 499-503.

SIDDONS R. C., PARADINE J., 1981. Effect of diet on protein degrading activity in the sheep rumen. J. Sci. Fd. Agric., 32, 973-981.

USHIDA K., JOUANY J. P., 1985. Influence des protozoaires sur la dégradation des protéines mesurées " in vitro " et " in sacco " 1ères Journ. Alim. Nutr. Herbiv., I.N.R.A., Paris, mars 1985. Reprod. Nutr. Dévelop., 1986, 26 (sous presse).

USHIDA K., JOUANY J. P., LASSALAS B., THIVEND P., 1984. Protozoal contribution to nitrogen digestion in sheep. Can. J. anim. Sci, 64, (suppl.) 20-21.

VEIRA D. M., IVAN M., JUI P. Y., 1984. The effect of ciliate protozoa on the flow of amino acids from the stomach of sheep. Can. J. anim. Sci., 64, (suppl.) 22-23.

VÉRITÉ R., DEMARQUILLY C., 1978. Qualité des matières azotées des aliments pour ruminant, 143-157. In "La vache laitière ». IX Grenier de Theix, I.N.R.A. Publ. éd., Rte de St-Cyr, 78000 Versailles, France.

WELLER R. A., PILGRIM A. F., 1974. Passage of protozoa and volatile fatty acids from the rumen of the sheep and from a continuous system in vitro fermentation. Br. J. Nutr., 32. 341-351. 